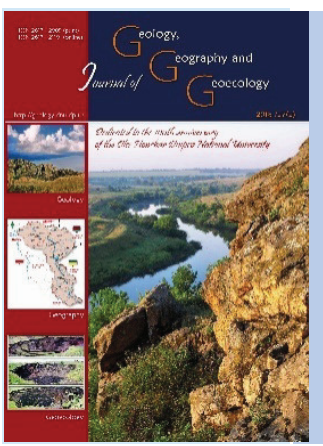

\section{Journal of Geology,} Geography and Geoecology

Journal home page: geology-dnu-dp.ua

\title{
Natural factors forming the quality of carbonate raw materials
}

Journ.Geol.Geograph. Geoecology, 27(3), 495-503 doi: $10.15421 / 111873$

\section{K.V. Repina}

\section{Donetsk National Technical University, Pokrovsk, Ukraine,ecoseka@rambler.ru}

Received 17.09.2018;

Received in revised form 25.09.2018; Accepted 18.10.2018

Abstract. The article is devoted to the study of natural factors that influence the regularities in the distribution of the quality of carbonate raw materials in the deposits of the Articulation Zone of the Donbass Basin with the Priazovskiy block of the Ukrainian Shield. Paleogeographic conditions of sedimentation and the processes of secondary quality change were established by comparing the lithologic-stratigraphic sections of deposits in different parts of the Articulation Zone: from the west (Novotroitskoe deposit) through the center (Elenovskoe deposit) and to the east (Karakubskoe deposit). The variability in the quality of carbonate raw materials was estimated from the results of statistical processing of the chemical analysis of exploratory samples. Geochemical associations were established for carbonate rocks within the stratigraphic horizons of each deposit. The best in quality of all deposits of the Donbass Articulation Zone are the carbonate rocks of the $\mathrm{C}_{1}^{\mathrm{t}} \mathrm{c}$ horizon. The conditions for their formation were the most stable. They are characterized by a negative connection of the main quality component $(\mathrm{CaO})$ with all other quality indicators. At the same time, the association of indicators associated with a significant positive connection is retained: $\mathrm{SiO}_{2}, \mathrm{R}_{2} \mathrm{O}_{3}$, S. The process of forming carbonate strata are accompanied by intense silicification processes that relate to climatic changes in temperature, salinity and depth of the sea basin. This is confirmed statistically, because the significant negative correlation between the main component of quality and silica is established on the horizons of carbonate rocks with an increased silica content. The process of dolomitization of the carbonate stratum took place in two stages. At the beginning of the accumulation of the carbonate layer, the sea basin was characterized by lower temperatures and higher magnesium contents than in the subsequent period. Therefore, the lower stratum of the Novotroitskoe and Elenovskoe deposits include sedimentary dolomites. Later, the conditions changed, so there are no dolomites in the Karakubskoe deposit. The second stage of dolomitization is associated with the post-carbon andesite-trachyandesite magmatic complex. The rocks of this complex are found in the carbonate stratum in the form of interplastic intrusions, dikes and stock-like bodies. This contributed to the appearance of sulphide mineralization, zones of silicification and recrystallization of carbonate minerals in spot-dolomitized limestones. The structural-tectonic factor, which is manifested by intensive leaching processes, exerts the greatest influence on the degradation of the quality of carbonate raw materials. In zones of tectonic disturbances, they have maximum extension areas. The structural transformations that began in the Donbas after the early Carboniferous disrupted the primary stratified occurrence and quality of the carbonate thickness. The upper Visean horizons are subject to intensively leached, similar to tectonic,melange. The contribution made by these studies to scientific knowledge lies in the identification of the natural factors that determined not only the quality of carbonate rocks, but also indicators of the development stages of the Donbass Articulation Zone of two major tectonic structures - Donbass and the Ukrainian Shield. The practical significance of the results of the work is connected with the fixed possibility of conducting geological and technological mapping and further construction of varietal maps of the deposits of carbonate raw materials.

Keywords: quality of the carbonate raw materials, the Donbass Articulation Zone, limestone deposit, stratigraphic horizon, structural-tectonic factor, formation conditions, correlation connection

\section{Природні фактори формування якості карбонатної сировини}

\section{К.В. Рєпіна}

\section{Донеџький Національний ТехнічнийУніверситет, м.Покровськ, Украӥна, ecoseka@ rambler.ruв}

Анотація. Стаття присвячена дослідженню природних факторів, що впливають на закономірності розподілу якості карбонатної сировини. Встановлено, що процес формування карбонатної товщі супроводжувався інтенсивними процесами окремніння, які пов'язані 3 кліматичними змінами температури, солоності і глибини морського басейну. Це підтверджено статистично, де на горизонтах карбонатних порід з підвищеним вмістом кремнезему, встановлений значущий негативний кореляційний зв'язок між основним компонентом якості і кремнеземом. Процес доломітізації карбонатної товщі проходив в два етапи. Спочатку, море захопило тільки південно-західну частину Зони зчленування. Умови формування карбонатної товщі характеризувалися більш низькими температурами і підвищеним вмістом магнію, ніж в наступний період. Тому самі нижні 
горизонти карбонатної товщі Новотроїцького та Оленівського родовищ включають осадові доломіти. Пізніше, умови змінилися, тому на Каракубському родовищі доломіти відсутні. Другий етап доломітізації пов'язаний з післякарбоновим андезиттрахіт-андезитовим магматичним комплексом. Породи цього комплексу залягають у вигляді міжпластовихинтрузій, i штокоподібних тіл у карбонатних породах. Це також пояснює наявність сульфідної мінералізації, зон окварцювання і перекристалізації карбонатних мінералів у плямисто-доломітізованих вапняках.Найбільший вплив на погіршення якості карбонатної сировини надає структурно-тектонічний фактор, який проявляється інтенсивними процесами вилуговування, розвиненими в зонах тектонічних порушень. Первісне шарувате залягання візейських стратиграфічних горизонтів карбонатної товщі просторово порушено. Тектонічним меланжем охоплені горизонти карбонатних порід нижнього карбону, починаючи $3 \mathrm{C}_{1}{ }^{\mathrm{d}} \mathrm{d} \mathrm{i}$ вище по розрізу.Наукова новизна наведених досліджень полягає у встановленні природних факторів, які визначили не тільки якість карбонатних порід, а й були індикаторами етапів розвитку Зони зчленування на стику двох великих структур Земної кори - Донбасу і Українського щита. Практичне значення результатів роботи пов'язане з подальшим проведенням геолого-технологічного картування на родовищах карбонатних порід.

Ключові слова: якість карбонатної сировини, Зона зчленування Донбасу, родовище вапняків, стратиграфічний горизонт, структурно-тектонічний фактор, умови формування, кореляційний зв'язок

Introduction. Carbonate rocks, including limestone, dolomite, chalk, and marl, are widely used both in agriculture and industry. The diversified use of carbonate raw materials requires strict compliance of its quality with the requirements of industries. The main useful component of carbonate raw material is calcium oxide $(\mathrm{CaO})$. This should be contained in the maximum quality. The magnesium content is limited within certain limits for electric steelmaking and ferroalloy production. With smelting in blast furnaces, magnesium is considered a useful component, because it reduces the melting point of the ore and makes slags rarer. The harmful impurities of carbonate raw materials are silica $\left(\mathrm{SiO}_{2}\right)$, sulfur, phosphorus and clay oxides $\left(\mathrm{R}_{2} \mathrm{O}_{3}\right)$. Their content should be minimal. The consistency of quality indicators, both physical and mechanical properties, and chemical composition, is closely related to the stability of sedimentation conditions. In Ukraine, the largest deposits of carbonate raw materials are located in the ArticulationZone, which divides the Donbass and the Priazovskiy block of the Ukrainian Shield. The exploitation of deposits is carried out in an open manner on the basis of the raw material quality forecast according to reconnaissance data. But among the blocks of high-quality raw materials the significant part of the carbonate reserves of the deposits are classified as substandard raw material. This is due to the wide spread of various transformations in carbonate rocks such as: dolomitization, leaching, silicification, sulfatization. The intensity and nature of these changes have a complex distribution both within individual deposits and throughout the ArticulationZone. They are associated with the long geological history of the region's formation. Effective exploitation of deposits is based on the forecasting of the quality of raw materials. This is a complex and urgent problem. Therefore, the purpose of this research is to determine the main factors which influence the distribution of raw material quality.

Latest achievements. Carbonate rocks have attracted the attention of many researchers, since their chemical activity promotes the appearance of mineral deposits of various genetic types. A variety of ore occurrences are known in the carbonate rocks of the ArticulationZone, such as uranium, gold, polymetals and fluorite (Panov, 2005; Chernicina, 2002; Kalashnik, 2017; Korenev, 2009; Nechaev, 1970). The most debatable issues are the sources of matter and the structural position of these ore occurrences. An important advantage for research is the presence of carbonate rock outcrops in the quarries, which are exploitedas carbonate raw materials deposits. This has allowed researchers not only to track the structures, but also draw conclusions about their development in connection with the well-known events in the history of the region (Machulina, 2008; Shatalov, 2013; Yudin, 2006). Geological conditions of the formation of carbonate deposits in the ArticulationZone have been considered repeatedly (Bakhtarova, 2006; Bakhtarova, 2016; Lazarenko, 1944; Ogar, 2010). But the reasons for the decline in quality of raw materials have not received sufficient attention. For other regions, similar studies were conducted (Gudz, 2007; Sokolov, 1962). The complex history of the developmentof the ArticulationZone as well as the presence of significant reserves of carbonate raw materials, the effectiveness of exploiting which is largely determined by the possibility of predicting its quality, determined the purpose of this study.

Research objective. The purpose of research is the study of natural factors affecting the quality of the carbonate raw materials.

Methodology of research. The work used the materials of exploration and mining of carbonate deposits in the Articulation Zone of the Donbass Basin with the Priazovskiy block of the Ukrainian Shield. These materials were obtained by the author in the course of industrial work and practical work towards a Master's degreeand also during postgraduate studies at the Donetsk National Technical University . It is known that the highest quality carbonate raw materials are formed in conditions of marine facies. Evaluation of the facial conditions on every stratigraphic horizon of deposits was per- 
formed on the composition of sediments and the presence of fossil fauna. Paleogeographic conditions of sedimentation were established by comparing the lithological-stratigraphic sections of deposits in different parts of the Articulation Zone: from the west (Novotroitskoe deposit) through the center (Elenovskoe deposit) and to the east (Karakubskoe deposit). Data from the chemical analysis of core samples was used for statistical data processing. Geochemical associations were defined within the stratigraphic horizons of each deposit through correlation analysis. Geochemical associations for high-quality limestones served as a benchmark for evaluation of the quality of secondary changes in carbonate rocks. The variability of the stratigraphic horizons capacity, the distribution and quality of secondary changes in carbonate rocks were studied also.

Geological and structural positions of carbonate raw materials deposits. Structurally, the research area is located on the southern wing of the Kalmius-Toretskaja depression. The length of the zone is several hundred kilometers with a width of about $25 \mathrm{~km}$ (Sobakar, 1961). The geological structure of the ArticulationZone is associated with the history of the formation and development of the DneprovoDonetskiypaleorift. Many researchers consider theArticulationZone with the Priazovskiy block of the Ukrainian shield as the South Donbas deep fault (Bakhtarova, 2006; Shatalov, 2013; Yudin, 2006). Along it the rocks of the crystalline basement sank to considerable depths, and a thick stratum of sedimentary and volcanogenic Paleozoic rocks accumulated. According to deep seismic sounding, the fault is clearly fixed in the relief of the Moho surface and probably penetrates to depths of at least $200 \mathrm{~km}$. One of the main proofs of its depth is the confinement of ultrabasic, basic and alkaline magmatism to it (Sobakar, 1961; Shatalov, 2013; Yudin, 2006).

In accordance with the stages of rifting, three structural floors (bottom-up) were formed: the Archaean-Proterozoic complex of crystalline rocks; Paleozoic volcanogenic-sedimentary and mezoCenozoic rock complexes. Two stages of tectonomagmatic activation are distinguished in the Devonian and on the boundary of the Permian and Triassic. The territory is limited by large faults of the sublatitudinal stretch in the south and in the north. They are called the North VolnovakhskiyFault and South VolnovakhskiyFault which dissect the rocks of the crystalline basement. The whole system of submeridional faults is divided into a series of anticlinal and synclinal structures. These include Novotroitskiy, Kamyshevakhskiy, Stylskiy, Elanchikskiy horsts and adjoning grabens, in which the deposits of carbonate rocks are located. In the process of formation of the Dnieper-Donets paleorift, structural-tectonic transformations had an alternating shear character, which led to the appearance of local areas of stretching and compression. In the early Carboniferous in the zone of formation of deposits of carbonate rocks, the Tournian and early Visean stratigraphic stages corresponded to the period of local extension (Bakhtarova, 2006). This led to a vast transgression of the sea, to increased communication with the outer seas, and to an increase in the species diversity of the coral fauna. The most favourablearea for the formation of limestones during the Tournian and Visean stratigraphic stages was the ArticulationZone(Ogar, 2010). The primary quality of the carbonate rocks of the studied area corresponds to the coastal-marine facies conditions that ensured the accumulation of thick layers of biomorphic limestones with almost no admixture of terrigenous material (Fig. 1).

Facies analysis of sediments showed that on the areas of all deposits there were similar living conditions for a diverse shallow marine fauna: represented by SpiriferdesinuatisLiss.,Productus Rot. sp. nov., SchellwinellacrenistriaPhill, Pustulapustulasiformis Rot., Athyris Lis Schuchertellabituminosa and others. The carbonate stratum of all deposits is characterized by a layered bedding form, a large amount of detrital material in the rock composition, as well as numerous fauna remnants in the rocks of most stratigraphic horizons.

Numerous changes in the conditions of sedimentation occurred throughout the entire territory during the Tournian and Visean stages: reduced the depth, temperature, and salinity of the basin. This is evidenced by changes in the chemical and facies composition of the sediments on each horizon: the presence of the arkose sandstone stratum (in the roof of the sub-horizon $\mathrm{C}_{1}{ }^{\mathrm{t}} \mathrm{b}_{1}$ ), thin strata of calcareous-argillaceous and carbonaceous schists $\left(\mathrm{C}_{1}{ }^{\mathrm{t}}\right.$, $\mathrm{C}_{1}{ }^{\mathrm{t}} \mathrm{b}, \mathrm{C}_{1}{ }^{\mathrm{v}} \mathrm{a}, \mathrm{C}_{1}{ }^{\mathrm{v}} \mathrm{e}$ ), silicified silty beds with flint nodules. The transgression of the Carboniferous Sea began on the area under study at different times. At first the sea seized the western part of the region (Novotroitskoe deposit) and then gradually moved to the east, reaching the area of the Karakubskoe deposit only by the end of the time $\mathrm{C}_{1}{ }^{\mathrm{t}} \mathrm{a}$ (Lazarenko, 1944).

The thicknesses and chemical composition of carbonate deposits of different stratigraphic strata are good evidence of this (Table 1).

Quality indicators of carbonate raw materials vary on horizons at each deposit, reflecting both the facial conditions of its formation and the secondary processes of changes in the quality of carbonate rocks. 


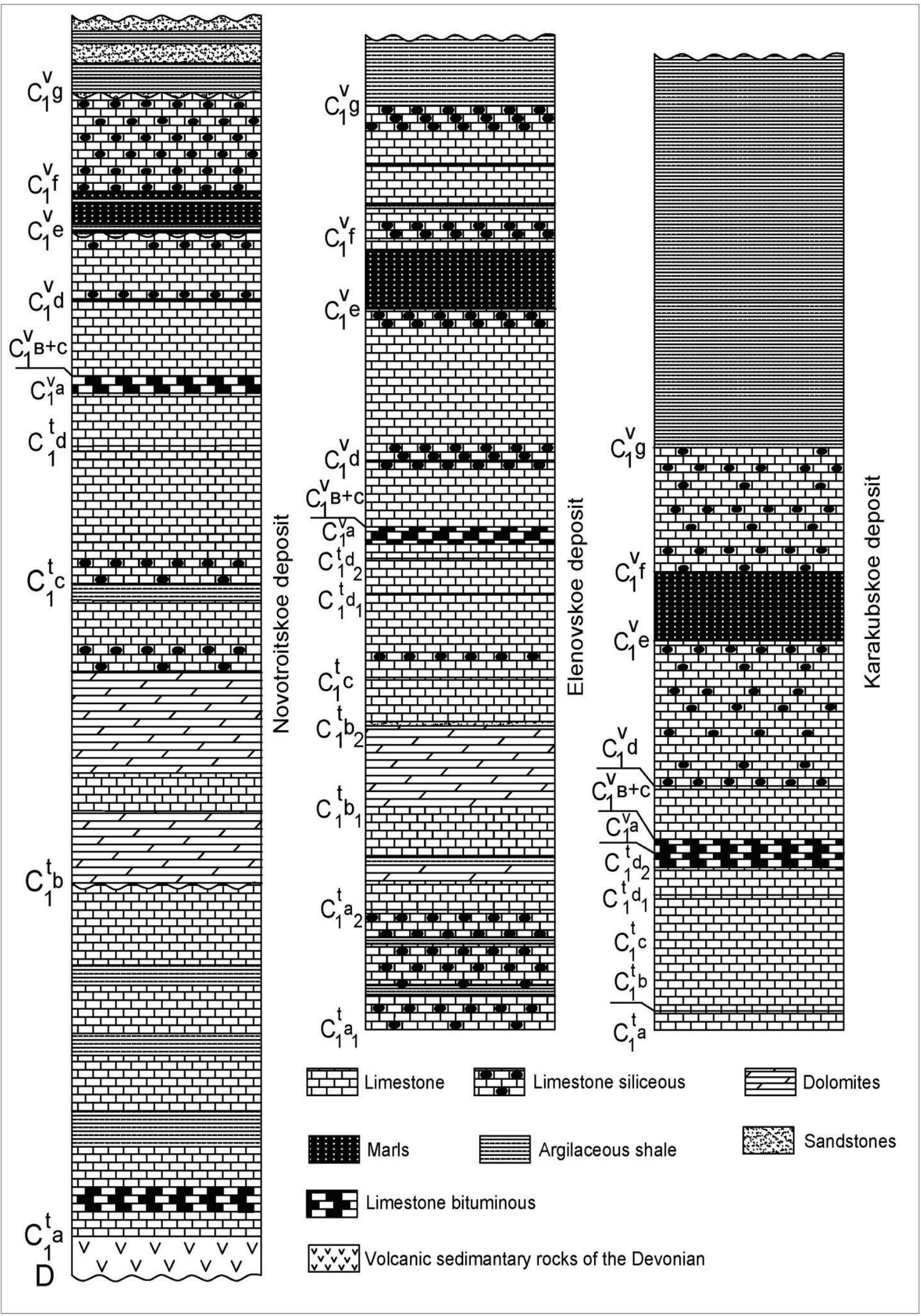

Fig. 1. Stratigraphic sediments of the early Carboniferous in the deposits of carbonate rocks 
Table 1. Quality of raw materials by stratigraphic horizons (according to data from work on the deposit)

\begin{tabular}{|c|c|c|c|c|c|c|c|c|}
\hline \multirow[b]{2}{*}{$\begin{array}{c}\text { Stratigraph. } \\
\text { horizon }\end{array}$} & \multirow[b]{2}{*}{ Nameofdeposit } & \multicolumn{6}{|c|}{ Quality indicators of carbonate raw materials, wt.\% } & \multirow{2}{*}{$\begin{array}{c}\text { Thickness } \\
\text { ofstratigraph. } \\
\text { horizons, } \mathrm{m}\end{array}$} \\
\hline & & $\mathrm{CaO}$ & $\mathrm{MgO}$ & $\mathrm{SiO}_{2}$ & $\mathrm{R}_{2} \mathrm{O}_{3}$ & $\mathrm{P} \cdot 10^{-2}$ & $\mathrm{~S} \cdot 10^{-2}$ & \\
\hline \multirow{3}{*}{$\mathrm{C}_{1}^{\mathrm{v}} \mathrm{d}$} & Novotroitskoe & 54.30 & 0.52 & 0.7 & 0.85 & 0.5 & 4.6 & 100.5 \\
\hline & Elenovskoe & 49.5 & 0.83 & 7.22 & 0.46 & 0.3 & 5.1 & 108 \\
\hline & Karakubskoe & 54.88 & 0.49 & 0.56 & - & & 4.5 & 100 \\
\hline \multirow{3}{*}{$\mathrm{C}_{1}^{\mathrm{v}} \mathrm{b}+\mathrm{c}$} & Novotroitskoe & 53.67 & 0.75 & 1.10 & 0.72 & 0.8 & 3.3 & 38 \\
\hline & Elenovskoe & 52.5 & 0.9 & 1.9 & 0.5 & & 0.5 & 36 \\
\hline & Karakubskoe & 54.53 & 0.68 & 0.77 & & 0.4 & 3.7 & 30 \\
\hline \multirow{3}{*}{$\mathrm{C}_{1}{ }^{\mathrm{v}} \mathrm{a}$} & Novotroitskoe & 54.83 & 0.64 & 0.94 & 7.78 & 0.8 & 18 & 3.6 \\
\hline & Elenovskoe & 47.2 & 1.4 & 6.8 & 2.11 & 0.3 & 2.2 & 5.5 \\
\hline & Karakubskoe & 38.32 & 1.42 & 23.51 & 4.83 & 5 & 47 & 8 \\
\hline \multirow{3}{*}{$\mathrm{C}_{1}^{\mathrm{t}} \mathrm{d}$} & Novotroitskoe & 21.74 & 0.63 & 0.49 & 0.21 & 0.8 & 2.4 & 28.7 \\
\hline & Elenovskoe & 52.8 & 0.9 & 2.1 & 0.83 & 0.3 & 6 & 19 \\
\hline & Karakubskoe & 54.62 & 0.55 & 0.68 & 0.22 & 0.5 & 6.2 & 24 \\
\hline \multirow{3}{*}{$\mathrm{C}_{1}{ }^{\mathrm{t}} \mathrm{c}$} & Novotroitskoe & 54.57 & 0.58 & 0.82 & 0.22 & 0.7 & 1.8 & 38.2 \\
\hline & Elenovskoe & 50.8 & 0.7 & 3.9 & 0.48 & 0.2 & 3 & 45 \\
\hline & Karakubskoe & 55.03 & 0.46 & 0.46 & 0.18 & 0.4 & 3.6 & 30 \\
\hline \multirow{3}{*}{$\mathrm{C}_{1}^{\mathrm{t}} \mathrm{b}$} & Novotroitskoe & 39.1 & 4.7 & 1.3 & 0.35 & 0.4 & 4.4 & 83.3 \\
\hline & Elenovskoe & 41.04 & 9.52 & 3.79 & 1.04 & 0.4 & 6 & 70 \\
\hline & Karakubskoe & - & - & - & - & & - & 32 \\
\hline \multirow{3}{*}{$\mathrm{C}_{1}^{\mathrm{t}} \mathrm{a}$} & Novotroitskoe & 42.71 & 9.60 & 2.11 & 1.16 & 0.5 & 1.7 & 135.7 \\
\hline & Elenovskoe & 37.6 & 10.6 & 4.9 & 0.1 & 0.3 & 7 & 119 \\
\hline & Karakubskoe & - & - & - & - & & - & 8 \\
\hline
\end{tabular}

The most stable in quality are the carbonate raw materials on the horizons $\mathrm{C}_{1}{ }^{\mathrm{t}} \mathrm{c}$ and $\mathrm{C}_{1}{ }^{\mathrm{t}} \mathrm{d}$. These are grey and dark-grey compact limestones with a large quantity of fossil fauna. But the homogeneous stratum of conditioned limestones in all deposits includes a pack of black compact limestones with inclusions of flint nodules. Perhaps, the salt composition and physicochemical characteristics $(\mathrm{pH}, \mathrm{Eh}$, Alk) of solutions varied widely, in comparison with the chemical composition of sea water. Accumulation of authigenic silica occurs together with organic matter in thin pelitic sediments of the marine basin (Senkovsky, 2012). Biogenic silica underwent particularly intensive transformation, which contri- buted to the redistribution of matter and the formation of nodules (Strakhov, 1976). The flintstones have a clear boundary with the limestones that surround them. Sometimes the flint nodules contain the remains of fauna. All this confirms their syngenetic origin. In general, this does not affect the high quality of raw materials of these horizons. The conditions for the formation of the carbonate strata at the end of the Tournian stage were stabilized throughout the ArticulationZone, as evidenced by the facial composition of the deposits. The thickness of the carbonate stratum is also practically the same in all deposits.

Table 2. Correlation relations between the main quality component $(\mathrm{CaO})$ and other quality indicators for high-quality carbonate raw materials

\begin{tabular}{|c|c|c|c|c|c|c|}
\hline \multirow[t]{2}{*}{ Deposit } & \multirow{2}{*}{$\begin{array}{l}\text { The sample size }(\mathrm{N}) \\
\text { and the critical correla- } \\
\text { tion coefficient }\left(\mathrm{r}_{\mathrm{cr}}\right)\end{array}$} & \multicolumn{5}{|c|}{ The correlation coefficients between the quality indicators } \\
\hline & & $\mathrm{MgO}$ & $\mathrm{SiO}_{2}$ & $\mathrm{R}_{2} \mathrm{O}_{3}$ & $\mathrm{~S}$ & $\mathrm{P}$ \\
\hline Novotroitskoe & $\mathrm{N}=54 ; \mathrm{r}_{\mathrm{cr}}=0,25$ & 0,11 & $-0,66$ & $-0,25$ & $-0,52$ & $-0,11$ \\
\hline Elenovskoe & $\mathrm{N}=58 ; \mathrm{r}_{\mathrm{cr}}=0,25$ & $-0,09$ & $-0,59$ & $-0,25$ & $-0,12$ & 0,21 \\
\hline Karakubskoe & $\mathrm{N}=50 ; \mathrm{r}_{\mathrm{cr}}=0,26$ & $-0,11$ & $-0,42$ & $-0,29$ & $-0,31$ & $-0,42$ \\
\hline
\end{tabular}

The mining of carbonate deposits assumes the production of one grade. This is complicated by the spread of processes that impair the properties of raw materials. Based on the chemical composition of the calcite $(\mathrm{CaO}=56 \%)$, variability of its content in the skeletal substance of coral fauna (Bakh- tarova, 2016), we made the representative sampling of the chemical analyses collected from highquality raw materials in each deposit. As a result of the correlation analysis of these "ideal" samplings, two associations of quality indicators were found connected by significant connections, which cha- 
racterizes all deposits. A positive connection is observed between the contents of $\mathrm{SiO}_{2}, \mathrm{R}_{2} \mathrm{O}_{3}, \mathrm{~S}$. These indicators reduce the quality of carbonate raw materials. The average value of the Pearson correlation coefficient for the entire association at a significance level $=0.05$ and at an average sample size $=55$ samples was $0.58\left(r_{a v}=0,58\right)$. The main quality indicator is associated with significant negative relationships with most of the components (Table 2).

Reduction in the concentration of calcium usually occurs due to the replacement of calcium cations in the lattice of the calcite mineral by other chemical elements (Predtechensky, 1961). There is a negative connection between the content of the main component $(\mathrm{CaO})$ and the content of the replacement component. The association of the indicators substitution associated with a negative significant connection $\left(\mathrm{r}_{\mathrm{av}}=-0.40\right)$ is represented in a very diverse way: $\mathrm{CaO}, \mathrm{SiO}_{2}, \mathrm{R}_{2} \mathrm{O}_{3}, \mathrm{P}$ (see Table 2). Depending on the secondary process, which degrades the quality of raw materials, the replacement association changes. We checked the associations for every stratigraphic horizon in all deposits. Therocksofthelowerhorizon $\left(\mathrm{C}_{1}{ }^{\mathrm{t}} \mathrm{a}\right)$ matchwithpoorqu ality. According to the lithological composition, they are transitional from the sandy-argillaceous sediments of the upper Devonian to the carbonate sediments of the early Carboniferous. That is darkgrey and black siliceous limestones with frequent interlayer sofcoaly-clayshales, sometimes sandstones. Two associations of quality indicators in these rocks were obtained. A positive connection is observed between contents of the $\mathrm{SiO}_{2}, \mathrm{R}_{2} \mathrm{O}_{3}$, and $\mathrm{S}$. They are similar to high-quality limestone associations (see Table 2). There placement association is represented by contents of $\mathrm{CaO}$, $\mathrm{MgO}, \mathrm{SiO}_{2}, \mathrm{R}_{2} \mathrm{O}_{3}, \mathrm{~S}$. Almost all the quality indicators have a significant negative connections with the main component of quality. The average value of the significant correlation coefficient is $\mathrm{r}_{\mathrm{av}}=-0.47$. The horizon $\mathrm{C}_{1}{ }^{\mathrm{t}} \mathrm{b}$ is folded by dense finegrained limestones, dolomitized limestones with a well-marked patchy texture, and dolomite, The processes of dolomitization are widespread on the Elenovskoe and Novotroitskoe deposits. Lower layers are spotted-dolomitized limestones, then overlying layers are represented by dolomites. Dolomite sand dolomitized limestone subhorizon $\mathrm{C}_{1}{ }^{\mathrm{t}} \mathrm{b}_{1}$ are characterized by more uniform granularity and degree of dolomitization and the absence of interbeds of shales. The main rock-forming minerals are dolomite and calcite. The dolomitization process is reflected by a high significant negative correlation coefficient between the contents of the main components of quality $\mathrm{CaO}$ and $\mathrm{MgO}(\mathrm{r}=-0.87)$.
The process secondary calcification is characteristic for the magnesian thickness of the horizons $\mathrm{C}_{1}{ }^{\mathrm{t}} \mathrm{a}_{2}$ and $\mathrm{C}_{1}{ }^{\mathrm{t}} \mathrm{b}$. The inclusions of calcite have a form of nests or veins ranging in size from several millimeters to 5-6 cm. Sometimes they make up to $15 \%$ of the rock volume. In these places among the inclusions of secondary calcite occur nests and fine grains of violet fluorite. All these facts point to the secondary nature of the dolomitization process. Some researchers associate the uneven dolomitization of the Tournian limestones with the postCarboniferous andesite-trachyandesite magmatic complex. The rocks of this complex lie in the form of interstratal intrusions, dikes and stock-like bodies (Nechaev, 1970). Perhaps the sedimentary dolomites are also present. The process of their formation, apparently occurred at lower temperatures and with increased magnesium content in the seawater. It appeared mainly in the southwestern part of the basin. Therefore, the lower horizons of the Novotroitskoe and Elenovskoe deposits include sedimentary dolomites. Already on subhorizon $\mathrm{C}_{1}{ }^{\mathrm{t}} \mathrm{b}_{2}$ fine-grained limestones with traces of dolomitization prevail. Later, the water temperature increased, therefore, there are no dolomites in the Karakubskoe deposit. The increased content of magnesium provided a conditioning indicator of the total content of calcium and magnesium oxides. Therefore, these raw materials were mined for the metallurgical industry. At the Karakubskoe deposit, these horizons were not worked out.

The processes of secondary mineralization are widely manifested in rocks of the $\mathrm{C}_{1}{ }^{\mathrm{t}} \mathrm{b}$ horizon. The works of many researchers are devoted this processes (Chernicina, 2002; Kalashnik, 2017; Korenev, 2009). Most of them connect these processes with the Devonian volcanism this region. Piritization manifests itself in the form of thin veins and nests along bedding planes, as well as in shallow cracks and caverns. The size of pyrite forms does not exceed a few centimeters. The sulphidization process caused the appearance of ore manifestations in the carbonate stratum (Panov, 2005). The silicification of carbonate rocks is presented by the form of small caverns with transparent brushes and druses of quartz with crystals $0,5-5 \mathrm{~mm}$ in size. Violet fluorite appears in the form of thin membranes, small grains and nests. The superimposed mineralization processes affected the diversity of the associations of elements. The processes of silicification and leaching are most intensively manifested. They are characterized by the association of $\mathrm{SiO}_{2}, \mathrm{R}_{2} \mathrm{O}_{3}, \mathrm{~S}\left(\mathrm{r}_{\mathrm{av}}=0.58\right)$.

The facial conditions in the beginning of the Visean stratigraphic stage again become unstable. The $\mathrm{C}_{1}{ }^{\mathrm{v}} \mathrm{a}$ horizon is represented by siliceous bituminous fine-grained limestones of black colour 
with intercalations of carbonaceous shales and a large number of marine fauna. The raw material of this horizon is considered substandard. The $\mathrm{C}_{1}{ }^{\mathrm{v}} \mathrm{a}$ stratigraphic horizon has a small thickness, constant lithological composition both on the dip and on the strike. So it is the marking horizon in all studied deposits. Correlation analysis established an extended paragenetic association of elements bound by a significant positive bond $\left(\mathrm{r}_{\mathrm{av}}=0.44\right)$ : $\mathrm{MgO}$, $\mathrm{SiO}_{2}, \mathrm{R}_{2} \mathrm{O}_{3}, \quad \mathrm{~S}$. The replacement association is represented by $\mathrm{CaO}, \mathrm{MgO}, \mathrm{SiO}_{2}, \mathrm{R}_{2} \mathrm{O}_{3}, \mathrm{P}$.

The raw material of upper horizons $\mathrm{C}_{1}{ }^{\mathrm{v}} \mathrm{b}$ and $\mathrm{C}_{1}{ }^{\mathrm{v}} \mathrm{c}$ has a high quality, constant chemical composition and so they are worked out together in all deposits. Associations of quality indicators are similar to "ideal" samples (see Table 2). The above horizon $\mathrm{C}_{1}{ }^{\mathrm{v}} \mathrm{d}$ is divided by quality into three subhorizons. The upper and middle subhorizons have an elevated silica content. Silica is present both in a diffusive form (in the form of lenses) and as flint nodules. This confirms the variability of the sedimentation conditions, when the physicochemical conditions changed the intensity of the processes of diagenetic silicon redistribution. Additionally, interbeds of clay shales are presented with thickness of up to 5 $\mathrm{cm}$. The average subhorizon has a thickness about 30 meters and good quality (see Table 1). Associations of quality indicators are similar to the reference ones (see Table 2). But the horizon $\mathrm{C}_{1}{ }^{\mathrm{v}} \mathrm{d}$ is spatially not sustained. Blocks of high quality are alternated with substandard blocks. In most quarries, only fragments of this horizon can be traced. At the Karaibskie deposit, the raw material of this horizon has small remaining forms, so here it is not worked out. All other upper strata of the Vizeageochronological stage are largely dislocated and subject to secondary changes (Yudin, 2006). The rocks are leached, partially brecciated and crushed.

At the end of the early Carboniferous the sea gradually became shallow. The period of pulsating warping of the Donbass basin began. Stable marine conditions periodically began to change to continental conditions. The horizonof $\mathrm{C}_{1}{ }^{\mathrm{v}} \mathrm{e}$ is represented by siliceous thin layers of dark-grey marls with interbeds of shales. The upper horizon of $\mathrm{C}_{1}{ }^{\mathrm{v}} \mathrm{f}$ is composed of fine-grained siliceous limestones containing a large quantity of flint nodules, with thin interbeds of clay shales. The horizon $\mathrm{C}_{1}{ }^{\mathrm{v}} \mathrm{g}$ consists of sandy-argillaceous and argillaceous shales with thin interbeds of limestone and coal (Lazarenko, 1944). These horizons are practically absent within the deposits. The nearly Carboniferous sediments were covered by a thick stratum of sandy-argillaceous shales with thin interlayers of coals and limestones of the middle and late Carboniferous. Further structural and tectonic transformations during the long history of the Donbass Articulation Zone with the Priazovskiy Block of the Ukrainian Shield changed the spatial patterns of the primary quality of carbon ate raw materials.

The main difficulty for predicting quality is the leaching process. Their distribution is determined by increased permeability of rocks, which is one of the main conditions for their development (Sokolov, 1962)., This process develops most intensively in zones of fracturing. The degree of tectonic disturbance in certain parts of the carbonate thickness depends on their position in the structural zones. The most intensive spread of karst is observed on the sites which are adjoined to a large disjunctive dislocation, saddle parts of anticlines, areas of convergence of large thrusts and faults (Gudz, 2007).

On deposits of carbonate raw materials, the karst processes are manifested in the form of various karst forms: funnels, caves, caverns, cracks, canals and others. The karst cavities are often made of loose sandy-argillaceous material, rarely remain empty. Observation in the quarry showed that the karst zones have a zonal structure. The walls of the karst cavities are usually represented by strongly destroyed loose carbonate rocks. Further, clays of various colours are observed toward the center of the cavity. The central part of the cavity is usually made of sandy-argillaceous material with fragments of primary rocks. The material filling the karst cavities, during working off, is extracted separately and transported to the dumps, which makes mining difficult.

To determine the regularities of karst distribution in the fields, operational exploration is carried out, which is aimed at delineating and calculating the volumes of karst zones by means of a linear coefficient of karst formation. This is the ratio of the karst rocks thickness to the total thickness of the rocks, expressed as a percentage. The coefficient of karst formation is calculated separately for each horizon and subhorizon of rocks (Table 3 ).

Table 3. Average coefficient of karst formation along stratigraphic horizons(according to mining)

\begin{tabular}{|c|c|c|c|c|c|c|c|c|c|}
\hline \multirow{2}{*}{ Deposit } & \multicolumn{7}{|c|}{ Average coefficient of karst formation along stratigraphic horizons, \% } \\
\cline { 2 - 11 } & $\mathrm{C}_{1}{ }^{\mathrm{v}} \mathrm{d}$ & $\mathrm{C}_{1}{ }^{\mathrm{v}} \mathrm{b}+\mathrm{c}$ & $\mathrm{C}_{1}{ }^{\mathrm{v}} \mathrm{a}$ & $\mathrm{C}_{1}{ }^{\mathrm{t}} \mathrm{d}$ & $\mathrm{C}_{1}{ }^{\mathrm{t}} \mathrm{c}$ & $\mathrm{C}_{1}{ }^{\mathrm{t}} \mathrm{b}_{2}$ & $\mathrm{C}_{1}{ }^{\mathrm{t}} \mathrm{b}_{1}$ & $\mathrm{C}_{1}{ }^{\mathrm{t}} \mathrm{a}_{2}$ & $\mathrm{C}_{1}{ }^{\mathrm{t}} \mathrm{a}_{1}$ \\
\hline Novotroitskoe & 25 & 20 & 39 & 14 & 13 & 22 & 22 & 4 & 43 \\
\hline Elenovskoe & 13 & 14 & 36 & 18 & 33,8 & 14,2 & 20,6 & 16,6 & 15,9 \\
\hline Karakubskoe & 13 & 14 & 36 & 15 & 18 & 64 & 18 & 12 & 22 \\
\hline
\end{tabular}


In the karstic carbonate rocks, in comparison with the average content of the quality indicators for horizons (see Table 1), the content of the useful component $(\mathrm{CaO}$ below $40 \%)$ sharply decreases. The content of insoluble residue, silica, alumina and iron $\left(\mathrm{R}_{2} \mathrm{O}_{3}\right)$ significantly increases. In the areas of crumpling and shattering of carbonate rocks, the intensity of sulfidization processes also increases significantly. The sphalerite-galena-calcite vein was established among the limestones of the horizons $\mathrm{C}_{1}^{\mathrm{t}} \mathrm{d}$ and $\mathrm{C}_{1}{ }^{\mathrm{v}}$ a of the southern quarry of the Komsomolskoe mine (Panov, 2005). Elevated gold concentrations were detected in karst and suffosion funnels of carbonate strata (Chernicina, 2002). This confirms the hypothesis of the hydrothermalmetasomatic origin of these ore occurrences.

It was established by correlation analysis that the leaching processes are characterized by a significant positive correlation of the indices: $\mathrm{MgO}, \mathrm{SiO}_{2}$, $\mathrm{R}_{2} \mathrm{O}_{3}$, S and a significant negative connection between $\mathrm{CaOMgO}, \mathrm{SiO}_{2}, \mathrm{R}_{2} \mathrm{O}_{3}$, P. Similar associations were established for carbonate horizons of the $\mathrm{C}_{1} \mathrm{v}$ a horizon, which is characterized by maximum karst content (see Table 3). The established associations of quality indicators are quite stable across all stratigraphic strata of the fields. This makes it possible to carry out geological and technological mapping, which are aimed at planning of the extraction of uniform quality carbonate raw materials (Volkova, 2015). Further studies will be aimed at constructing varietal maps of the distribution of carbonate raw materials of uniform quality for the adopted technology for mining the deposit. The complex geochemical index that will be used in mapping is based on established geochemical associations. The accuracy of the selection of grade composition within the deposits will be considered in a separate article.

Findings. As a result of the research it was established that:

1. The process of forming carbonate strata is accompanied by intense silicification processes that relate to climatic changes in temperature, salinity and depth of the sea basin. This is confirmed statistically, because the significant negative correlation between the main component of quality and silica is established on the horizons of carbonate rocks with an increased silica content.

2 . The process of dolomitization of the carbonate stratum took place in two stages. At the beginning of the accumulation of the carbonate thickness, the sea basin was characterized by lower temperatures and higher magnesium content than in the subsequent period. Therefore, the lower stratum of the Novotroitskoeand Elenovskoe deposits includes sedimentary dolomites. Later, the conditions changed, so there are no dolomites in the Kara- kubskoe deposit. The second stage of dolomitization is associated with the post-carbon andesitetrachyandesite magmatic complex. The rocks of this complex are found in the carbonate stratum in the form of interplastic intrusions, dikes and stocklike bodies. This contributed to the appearance of sulphide mineralization, zones of silicification and recrystallization of carbonate minerals in spotdolomitized limestones.

3. The best in quality for all deposits of the Donbass Articulation Zone are the carbonate rocks of the $\mathrm{C}_{1}{ }^{\mathrm{c}} \mathrm{c}$ horizon. The conditions for their formation were the most stable. They are characterized by a negative connection of the main quality component $(\mathrm{CaO})$ with all other quality indicators. At the same time, the association of indicators associated with a significant positive connection is retained: $\mathrm{SiO}_{2}, \mathrm{R}_{2} \mathrm{O}_{3}$, S.

4. Depending on the process which degrades the quality of raw materials, the replacement association changes, reflecting the negative significant connection of the main indicator with the rest.

5. The structural-tectonic factor, which is manifested by intensive leaching processes, exerts the greatest influence on the degradation of the quality of carbonate raw materials. In zones of tectonic disturbances, they have maximum extension areas. The structural transformations that began in the Donbas after the early Carboniferous disrupted the primary stratified occurrence and quality of the carbonate thickness. The upper Visean horizons are subject to intensively leached, similar to tectonic,melange.

6. On each stratigraphic horizon, depending on the prevailing process which degrades the quality of primary carbonate rocks, the correlation bonds of the main quality component and the harmful impurity replacing it (the replacement association) change. The most stable association of indicators associated with a significant positive bond is $\mathrm{SiO}_{2}$, $\mathrm{R}_{2} \mathrm{O}_{3}$, S. It is present practically on all horizons.

7. Stable associations of quality indicators make it possible to carry out technological mapping in deposits of carbonate raw materials, aimed at the separation of homogeneous blocks of raw materials and their further processing. The complex geochemical indicator that will be used in mapping is based on fixed geochemical associations.

8. The scientific novelty of these studies is the distinguishing of natural factors that determined not only the quality of carbonate rocks, but also indicators of the development stages of the Donbass Articulation Zone of two major tectonic structures the Donbass and the Ukrainian Shield. The practical significance of the results of the work is connected with the fixed possibility of conducting geological and technological mapping and further con- 
struction of varietal maps of the deposits of carbonate raw materials.

\section{References}

Bakhtarova E.P., Privalov V.A., 2006.Vliyaniye tektonicheskikh usloviy na vidovoye raznoobraziye korallov karbona Donetskogo basseyna [Influence of tectonic conditions on the species diversity of the corals of the Donets basin carbon]. Scientific works of DonNTU, a series of mining and geological. 111. 7-15 (in Russian).

Bakhtarova E.P., Privalov A.V., 2016. Osobennosti khimicheskogo sostava skeletnykh ostatkov korallov iz otlozheniy srednego I verkhnego karbona Donbassa [Features of the chemical composition of skeletal remains of corals from the deposits of the middle and upper Carboniferous of Donbass].News of Donetsk Technical University.2 (39).41-46(in Russian).

Chernicina O., 2002. Mineral'ni asotsiatsiyi nyz'ko temperaturnykh metasomatytiv, yaki suprovodzhuyut' zolote zrudeninnya (Dokuchayivs'kyyrudnyy rayon) [Mineral associations of low-temperature metasomatites that accompany gold mineralization (Dokuchaevsky ore district)].Mineralogy zbirnik. 52. $72-77$ (in Ukrainian).

Gudz M.M., Trubachev A.I., 2007. Osnovnyye zakonomernosti razmeshcheniya mestorozhdeniy i proyavleniy karbonatnogo syr'ya Zabaykal'ya [The main regularities of the location of deposits and manifestations of carbonate raw materials of Transbaikalia]. Mountain Information and Analytical Bulletin (scientific and technical journal). 4. 213-219 (in Russian).

Kalashnik A.A., 2017. Metallogenicheskoye raznoobraziye Volnovakhskoy rudnoy zony Priazovskogo megabloka Ukrainskogo shchita [Metallogenic diversity of the Volnovakh ore zone of the Priazovsky megablock of the Ukrainian Shield]. Material of the International Geological Forum "Current Issues and Prospects for Geological Exploration: Science and Vibration" (Geoforum-2017) 19-24 of the chernivnya. 158-162 (in Russian).

Korenev V.V., Strekozov S.N., Yushin A.A., 2009. Perspektivy proyavleniy orudeneniya samorodnoy medi $\mathrm{v}$ bazal'toidakh zony sochleneniya Donbassa S Priazovskim blokom Ukrainskogo shchita [Prospects of mineralization of native copper in the basaltoid of the junction zone of the Donbas with the Priazovsky block of the Ukrainian Shield]. NaukovipratsiUkrNDMI NAN Ukraine.5, part 2.247-252(in Russian).

Lazarenko E.K., Panov B.S., Gruba V.I., 1944. Geology of the USSR. T.7. Donetsk pool, ed. akadem. P.I. Stepanova. - Gos. com. pub. on geology under the Council of People's Commissars of the USSR.

Machulina S.A., 2008. Geologicheskiye usloviya formirovaniya "chernogo kuril'shchika" v Donbasse
[Geological conditions for the formation of a "black smoker" in the Donbass]. Reports of the National Academy of Sciences of Ukraine. 12. 107-110(in Russian).

Nechaev S.V., 1970. Mineralizatsiya Volnovakhskoy zony razlomov [Mineralization of the Volnovakha fault zone].

Ogar V.V., 2010. Orhanohenni sporudy karbonu Donets'koho baseynu ta deyaki osoblyvosti yikh formuvannya [Organogenous formation of the Carboniferous of the Donets Basin, and some peculiarities of their formation. Zbirnik Naukovych prac. IGN NASU. 3. 81-87 (in Ukrainian).

Panov B.S., Alekhin V.I., 2005. Strukturno-teksturnyye osobennosti i mineral'nyy sostav novogo polimetallicheskogo proyavleniya zony YuzhnoDonbasskogo glubinnogo razloma [Structural and textural features and mineral composition of the new polymetallic manifestation of the zone of the South Donbas deep fault]. Bulletin of the National Mining University.Geology. 6. 12-15 (in Russian).

Predtechensky N.N., 1973. Fatsii i geokhimiya karbonatnykh otlozheniy [Facies and geochemistry of carbonate deposits].132 (in Russian).

Senkovsky Y.M., Koltun Y.V., Grigorchuk K.G., 2012 Bezkysnevi podiyi okeanu [Bezkysnevi podiyi okeanu]. 183 (in Ukrainian).

Shatalov N.N., 2013. Strukturno-geologicheskiye usloviya lokalizatsii shtokov i dayek andezittrakhiandezitovogo kompleksa zony sochleneniya Donbassa s Priazov'yem [Structural-geological conditions for the localization of stocks and dikes of the andesite-trachyandesite complex of the joint zone of the Donbass and the Azov Sea]. Mineral Resources of Ukraine.4. 27-31 (in Russian).

Sobakar G.G., 1961. Struktura zony sochleneniya Donbassa s Priazovskim massivom [Structure of the zone of articulation of the Donets Basin with the Azov Massif].Geology Journal. 3. 60-65 (in Russian).

Sokolov D.S., 1962. Osnovnyye usloviya razvitiya karsta [The main conditions for the development of karst]. 322 (in Russian).

Strakhov N.M., 1976. Problemy geokhimii sovremennogo okeanskogo litogeneza [Problems of geochemistry of modern oceanic lithogenesis]. Science. 300 (in Russian).

Volkova T.P., Repina K.V., 2015.Geological technology of grade mapping of non-metallic raw materials as the basis of its profitable mining. Theoretical and Practical Solutions of Mineral Resources Mining / CRC Press Taylor \&Fransis Group, A BALKEMA BOOK.363-367 (in English).

Yudin V.V., 2006. TektonikaYuzhnogoDonbassairudogenez [Tectonics of the Southern Donbass and oreogenesis].UkrGGRI.108 (in Russian). 